\title{
Estimating Equilibrium Real Exchange Rates in the Franc Zone*
}

\author{
Simeon Coleman ${ }^{\dagger}$ \\ Department of Economics, University of Leicester, Leicester, LE1 7RH.
}

\begin{abstract}
In the CFA Franc zone of sub-Saharan Africa, the collective devaluation in 1994 remains the most important incident in its history. It sought to put an end to the worsening overall macroeconomic position of the zone. Using seemingly unrelated regression equations (SURE) analysis, this paper estimates the real effective exchange rate and degree of misalignment in 12 Franc zone countries over the period 1960-99, allowing for contemporaneous error covariance due to observed cross-sectional dependence. The evidence suggests some significant differences among member states, however the largest economies - Cameroon, Côte d'Ivoire and Senegal - showed some striking similarities: just prior to the devaluation, they were much more overvalued relative to the smaller member states, most of which were either only marginally misaligned or virtually in equilibrium. In 1994, only Côte d'Ivoire is exactly in equilibrium as a result of the devaluation. Analysis of the post-1994 period suggests that some challenges lie ahead for the Franc zone, if fixed parity is to be maintained.
\end{abstract}

Keywords: CFA Franc zones, Real effective exchange rates, Cross-sectional dependence JEL: C32, F33, F42, P47

\footnotetext{
${ }^{*}$ I am grateful to Dr. Rodney Strachan, Prof. Mustafa Caglayan, Prof. David Fielding, Prof. Gianni de Fraja and especially two anonymous referees for helpful comments and suggestions. Any remaining omissions and errors are mine.

${ }^{\dagger}$ E-mail: sc126@le.ac.uk. Tel: 0116252 5078/5338; Fax: 01162522908.
} 


\section{Introduction}

Episodes such as the Brazilian devaluation of 1999, the Asian crisis of 1997, the Mexican currency crisis of 1994 and the devaluation of the CFA Francs of west and central Africa in 1994 have shown that growing financial integration has increased the costs associated with real exchange rate (hereafter RER) misalignment, and underscore the importance of avoiding such misalignments. ${ }^{1}$ Consequently, the increasing evidence of deliterious consequences associated with RER misalignments combined with the formation of the European Monetary Union, have spurned a huge increase in research related to such misalignments. The aim of this paper is to complement such research by estimating the degree of misalignment in the RER within member countries of the CFA Franc zone of sub-Saharan Africa over the period 1960-99. ${ }^{2}$

Typically, estimation of equilibrium RER is non-trivial and in most developing countries this problem is compounded by the lack of sufficient historical data. Devarajan (1997) highlights some of these difficulties associated with various methods of estimating misalignment. Intuitively, a country's international competitiveness in foreign trade hinges on the level of the RER. On the one hand, an overvalued RER is likely to lead to a loss of competitiveness, which in turn implies hindered growth and slower convergence. Furthermore, an overvalued RER, according to theory, opens up a currency to speculative attacks and thus capital flight. On the other hand, an undervalued RER implies higher inflationary pressures since real appreciation will only be able to take place through higher inflation. Although high inflation is itself not a preferred state, 'tolerable' thresholds can differ significantly among countries. In fact, misalignments in the RER affects short-term capital flows and hence central bank balance sheets, thereby affecting monetary policy. The practical importance of the RER and misalignments make it one of the most debated issues in both theoretical and applied research on national and international macroeconomic policy. ${ }^{3}$

Traditional approaches for estimating the equilibrium RER include the purchasing power

\footnotetext{
${ }^{1}$ In this paper misalignment in a given period $t$ is defined as the percentage difference between the real effective exchange rate and the calculated equilibrium value in that period.

${ }^{2}$ The 8 west African countries (sometimes called the Communauté Financière Africaine) and 6 central African countries (sometimes called the Cooperation Financière en Afrique Centrale) that make up the CFA Franc zone each have a different currency (both called the CFA Franc), but are equally pegged to the French Franc (now to the Euro) with convertibility guaranteed by the French Treasury. See for example Fielding (2002) pp. 1-14 for a review of the institutional arrangements with the CFA Franc zone.

${ }^{3}$ Estimating Equilibrium Exchange Rates (1994), John Williamson (ed.) provides some insight into some of these debates and the lack of concensus on estimating the equilibrium exchange rate. Also, an extensive review of both theoretical and empirical issues related to definition, measurement, determinants and estimation of the real exchange rate is provided by Lawrence Hinkle and Peter Montiel (eds.) in Exchange Rate Misalignment Concepts and Measurement for Developing Countries (1999).
} 
parity (PPP) approach (see examples Officer,1982 and DeGregorio and Wolf,1994) and the trade-elasticities approach (see Krueger et al., 1988). ${ }^{4}$ Despite these two broad approaches, some variations exist and there seems to be a concensus among researchers that there are situations in which each is applicable. In fact, the main issues of contention regarding long-run equilibrium real exchange rate (LRER) are partly conceptual and partly empirical. Broadly speaking, most researchers agree with Nurkse's (1945) definition of the LRER, but differ on what constitutes the best choice of determinants and empirical approach. ${ }^{5}$ In principle, changes in RER can be captured in many ways: using traditional single-equation reduced-form model (Edwards, 1989, 1994; Razin and Collins, 1997), by using cointegrating equations (Elbadawi, 1994; Elbadawi and Soto, 1994; Baffes et al., 1999). However, in testing for the presence of unit-roots and determining the presence of cointegration between RER and the 'fundamentals', the standard unit-root tests (for example ADF tests and Im et al. (2003) [IPS] tests) typically assume that errors are independent between countries. Coakley et al. (2005), O'Connell (1998), and Pesaran (2007) have shown that such assumptions can provide misleading results. Specifically, in multicountry analysis of RER misalignment, methods that ignore cross-sectional dependence are likely to provide misleading estimates and hence incorrect equilibrium(s).

This paper focuses on the behaviour of the real effective exchange rate (REER) within the CFA Franc zone of Africa which has been in existence since 1948, and is currently made up of fourteen different mainly former French colonies that have come together to form two monetary unions. The fixed parity with the French Franc has been adjusted only once in January of 1994 through a $100 \%$ collective devaluation. Although debate related to the need, or otherwise, for this landmark devaluation goes beyond the issue of RER misalignment, it has been considered to be an important factor in research concerning the devaluation. Many important questions arise in relation to the CFA Franc zone and RER misalignment in light of the landmark 1994 collective devaluation. I attempt to address some of these questions: were all the CFA Franc zone countries overvalued in the 1970s and 1980s, as is widely believed for most African countries (see Dollar, 1992)? What was the behaviour of the RER in individual member-countries in the period leading to 1994 to prompt the collective devaluation? How severe was the degree of misalignment

\footnotetext{
${ }^{4}$ The PPP approach takes the equilibrium RER as the value observed in the year when the current account is taken to be in equilibrium, and calculates the misalignment in other periods. The trade-elasticities approach defines the RER as the price of imports or export divided by the CPI and for a desired current account level, the level of depreciation necessary can be computed.

${ }^{5}$ Nurkse, R. (1945) defines the LRER as that value of the RER consistent with external and internal balance conditioning on specified values of other variables that may influence these balances. Also see Edwards (1989) for a more recent deposition.
} 
in member-states just prior to the 1994 collective devaluation? How different has been the path of the RER in member countries after the 1994 devaluation? Increased information about answers to these questions is particularly relevant for current and future policy within the CFA Franc zone. Particularly, an analysis which takes into account possible error dependence seems particularly relevant for these countries due to inherent economic dependency, spatial spillover effects and fundamental institutional arrangements.

The policy implications of the above questions call for a methodology that explores the period including the 1994 devaluation itself, and also accounts for cross-country error-dependence. In this paper, I attempt to improve on previous research by making use of the fundamentals approach, from which policy concerns can be addressed. Secondly, I conduct panel unit-root tests that account for cross-sectional dependence by making use of a novel test proposed in an earlier version of Pesaran (2007). Furthermore, I use seemingly unrelated regression (SURE) model estimations which allows for contemporaneous error covariance. ${ }^{6}$ Finally, this paper attempts to distinguish between misalignment based on two alternative 'equilibrium' RER the short-run equilibrium (SRER) and long-run equilibrium (LRER) real exchange rates. ${ }^{7}$ I find significant variation in observed misalignments across member-states, but also uncover some interesting similarities; particularly between the large economies, which underwent the steepest RER appreciation just prior to the collective devaluation. This paper suggests that this situation may have played a major role in the zone's decision to devalue.

The rest of the paper is organised as follows. Section 2 discusses issues related to determinants of the real exchange rate. Section 3 describes the specification of the real exchange rate equation and empirical methodology. The data and empirical results are presented in Section 4. Section 5 provides some concluding remarks.

\section{Real exchange rates in the CFA Franc zone}

The RER is generally defined as the nominal exchange rate adjusted for price level differences between countries. This paper takes into account the major trading partners of each of the twelve Franc zone countries in the sample, hence the real effective (or multilateral) exchange

\footnotetext{
${ }^{6}$ The validity of this approach is later tested by testing for contemporaneous correlation in the error terms based on Lagrange Multipler statistic $(\lambda)$.

${ }^{7}$ Here, SRER refers to the value of the REER observed in the absence of speculative (bubble) factors; whiles LRER is a function of the steady-state values of any predetermined variables and permanent (sustainable) values of the policy and exogenous variables, obtained by exponentially smoothing the individual series.
} 
rate (REER). RER $_{t}$ may be represented as:

$$
R E R_{t_{i, j}}=E_{t_{i, j}} \times \frac{P_{t_{i}}}{P_{t_{j}}^{*}}
$$

where $P_{t_{i}}$ refers to the domestic price level, $P_{t_{j}}^{*}$ to the foreign country price level converted into domestic CFA Francs, and the individual country bilateral nominal exchange rate in period $t$ as $E_{t_{i, j}}$. Based on equation 1, the real effective exchange rate $\left(\mathrm{REER}_{t_{i}}\right)$ can therefore be written as: ${ }^{8}$

$$
R E E R_{t_{i}}=e_{t_{i}}=\prod_{j=1}^{n} R E R_{t_{i, j}}^{w_{j}}
$$

where $n$ represents the number of trading partners of country $i$, and weight $w_{j}$ the trade with trading partner $j$ as the share of country $i$ 's overall trade. By this definition, an increase in the REER (equation 2) index implies appreciation of the real effective exchange rate, and a decrease implies depreciation.

\subsection{Determinants of the real exchange rate}

This section briefly discusses the theory which motivates the choice of determinants of the RER.

The Balassa-Samuelson effect is usually considered to represent domestic supply-side influences, and may be represented by an asymmetric productivity shock favouring the traded-goods sector. ${ }^{9}$ With a productivity shock that favours the traded-goods sector, research has generally shown that the equilibrium real exchange rate appreciates due to the excess demand created for non-traded goods and thus there is a tendency for the trade balance to improve.

In principle, changes in composition of government spending between traded and non-traded goods are considered to influence long-run real exchange rate. Any tax-financed increases in spending on traded goods are considered to impose downward pressure on the trade balance, and will require real depreciation to maintain the external balance. Alternatively, tax-financed increases in spending on non-traded goods create initial excess demand in that market and will require real appreciation to restore equilibrium.

\footnotetext{
${ }^{8}$ The use of the geometric mean, rather than the arithmetic mean, has the advantage of treating changes in the RER symmetrically and is not dependent on the choice of the base year.

${ }^{9}$ The Balassa-Samuelson effect suggests that an increase in the relative productivity of 'tradables' versus 'nontradables' of one country versus foreign countries raises its relative wage, thus increasing its relative price of 'non-tradables' and its relative average price, and inducing an appreciation of the real exchange rate (RER).
} 
Changes in international trade environment are usually captured by factors such as the terms of trade for the domestic economy, availability of external transfers, level of world interest rates and the world inflation rate. Improvements in the terms of trade may lead to an appreciation of the RER by improving the trade balance, and also by creating excess demand for non-traded goods. Alternatively, it may also result in an overall depreciation if these spending effects are overcome by substitution effects on the supply and demand sides. Reductions in world interest rates and increases in world inflation relative to domestic levels are generally considered to depreciate the RER through increases in capital inflows and the effects on transaction costs associated with real money balances respectively.

Finally, changes in commercial policy are usually proxied by some measure of trade liberalization, and are generally associated with depreciation in the equilibrium real exchange rate. The observed excess supply in non-traded goods sector plays a significant role in the nature of the adjustment in the real exchange rate.

\section{Econometric specification and methodology}

The specification used in this paper is based on a log-linearized form of the fundamentals approach to estimating the equilibrium RER (Williamson, 1994). Since RER is not directly observable, several combinations of fundamentals have been used to explain its movements. Ideally, one may consider a list of proxies for fundamentals including government spending on traded and also on non-traded goods, resource balance, productivity differentials between traded and non-traded goods, the terms of trade and an appropriate measure of the international economic environment and commercial policy. ${ }^{10}$

Although there is no absolute consensus regarding determinants, this paper identifies a set of variables that may potentially act as long-run fundamentals and attempts to determine the nature of their influence on the long-run RER. These include domestic supply-side factors, fiscal policy, changes in international economic environment and commercial policy. In this paper, along with several variables considered in Baffes et al. (1999), I include government consumption as a share of GDP to proxy changes in fiscal policy and then assume there exists a long-run

\footnotetext{
${ }^{10}$ Different sets of determinants have been considered by various studies. For some examples see Edwards (1989, 1994), Elbadawi (1994), Elbadawi and Soto (1994), Feyzioglu (1997), Clark and MacDonald, (1998), Baffes et al. (1999); Kim and Korhonen (2002).
} 
equilibrium real exchange relationship in log-linear form, which can be written as:

$$
\ln e_{t_{i}}^{*}=\beta_{i}^{T} F_{t_{i}}^{P}
$$

where $e_{t_{i}}^{*}$ is the equilibrium REER, $F_{t_{i}}^{P}$ represents the vector of permanent values of the fundamentals (also in natural logarithms), and $\beta_{i}^{T}$ is the transpose of the vector of long-run parameters of interest for country $i$. The empirical estimation of $\beta_{i}$ requires the use of observable variables, hence the model that captures the relationship may be written as:

$$
\ln e_{t_{i}}=\beta_{i}^{T} F+\varepsilon_{t_{i}}
$$

where $F$ represents the vector of observed fundamentals. I note that, the steady state has to be dynamically stable such that the RER will converge to its long-run equilibrium in equation 3 in the absence of any shocks.

Estimating the equilibrium RER for countries in the CFA Franc zone requires some additional considerations, particularly due to the unique institutional arrangements within the monetary union and data availability. Given the determinants of the RER, as described in section 2.1, data considerations require some compromises to be made as follows: investment as a share of GDP $\left(\mathrm{INVSH}_{t}\right)$ is used to capture the domestic supply capacity and possibly technological progress (see Kim and Korhonen, 2002); government consumption as a share of GDP $\left(\mathrm{GOVCON}_{t}\right)$ to capture the impact of changes in fiscal policy; and the terms of trade $\left(\mathrm{TOT}_{t}\right)$ is used to capture changes in international economic environment. In addition, resource balance is treated as one of the fundamentals, consistent with an assumption that Franc zone memberstates face an upward-sloping supply curve of external loans, thereby imposing a binding credit ceiling which shuts down the capital account and determes net interest payments. ${ }^{11}$ To capture the impact of commercial policy or trade regime, this paper uses a measure of openness to international trade $\left(\mathrm{OPN}_{t}\right)$.

Economic theory suggests that an increase in resource balance (associated with net capital inflow) will induce an increase in domestic absorption and shift the composition of potential output towards non-traded goods. However, as it may be argued that the RER is one of the primary determinants of the resource balance - one potential method is to use the lagged value

\footnotetext{
${ }^{11}$ For a more extensive discussion on this issue, see Hinkle and Montiel (1999), pages 12-13. See also Chapter 10. pages $410-412$.
} 
of resource balance to GDP ratio $\left(\mathrm{RBAL}_{t-1}\right)$ as a measure of the effects of net capital inflows. ${ }^{12}$ In equation 5 below, an attempt to account for the 1994 collective devaluation within the CFA Franc zone is made by using an impulse dummy variable (D94) which takes the value of 1 in 1994 and 0 otherwise.

In summary, the vector $F(z)$ represents $\mathrm{RBAL}_{t}$ (in levels), and $\mathrm{GOVCON}_{t}, \mathrm{INVSH}_{t}, \mathrm{TOT}_{t}$ and $\mathrm{OPN}_{t}$ (in natural logarithms) and $i$ the home country. For country $i$, the long-run of the REER may thus be represented by equation 5 below, which is consistent with equation 3 (see Appendix $B)$ :

$$
\ln e_{t_{i}}^{*}=\beta_{0_{i}}+\beta_{1_{i}}^{T} F(z)_{t_{i}}+\beta_{2_{i}} D 94_{t}
$$

where $\beta_{0_{i}}$ represents the intercept, $F(z)_{t_{i}}$ is the vector of fundamentals, and $t=1,2, \ldots, T$ are the time periods. The steady-state relationship between RER and its fundamentals can therefore be estimated for each country using the relationship:

$$
\ln e_{t_{i}}=\beta_{0_{i}}+\beta_{1_{i}}^{T} F(z)_{t_{i}}+\beta_{2_{i}} D 94_{t}+\varepsilon_{i},
$$

where $\varepsilon_{i}$ is a mean-zero stationary random variable. As before, the steady state is required to be dynamically stable. Hence, shocks that cause the RER to diverge from its equilibrium in the short-run should, in the absence of any new shocks, produce eventual convergence to equation 5. Keeping in mind the possibility of significant cross-country residual correlations, OLS may not be efficient and the use of seemingly unrelated regression equations (SURE) estimations to improve efficiency is preferred.

When some of the variables in equation 6 are $I(1)$ in levels, and $\varepsilon_{i}$ is stationary then there exists at least one cointegration relationship and the corresponding long-run relationship is stable. The equilibrium RER can then be identified as that unobserved function of the fundamentals towards which the actual RER gravitates over time (Kaminsky, 1988; Elbadawi, 1994; Elbadawi and Soto, 1994, 1997; Kim and Korhonen, 2002). Although time series estimations have been used in many contexts to estimate the equilibrium RER (and misalignment) and to establish a long-run relationship between the RER and its fundamentals, this paper suggests that considering the effects of cross-sectional dependence will improve the results. ${ }^{13}$ While re-

\footnotetext{
${ }^{12}$ Hausmann tests for endogeneity of the RBAL and GOVCON was conducted and in both cases the tests do not reject the null of exogeneity in the data for all the countries in our sample (see Table 1). The term resource balance is used to refer to the the difference between the export and the imports of goods and nonfactor services as a share of GDP. For an in-depth discussion of endogeneity in the fundamentals see Hinkle and Montiel (1999).

${ }^{13}$ See examples Bacha and Taylor, 1971; Officer, 1982; Khan and Ostry, 1992; Devarajan et al., 1993;
} 
cent developments have brought about many methods of estimating the equilibrium RER, the suitability of these methods depends mainly on the nature and quantity of the data, and the purpose of the study. ${ }^{14}$ For our purposes, given nominal exchange rate peg within the Franc zone and guaranteed convertibility, an assumption of a common long-run equilibrium relationship in equation 6 across countries may seem reasonable (as in Pooled Mean Group approach, Pesaran, 1999). However, the formation of the CFA Franc zone was more on the basis of colonial arrangements rather than economic design and hence, one can also expect individual countries to exhibit some level of heterogeneity in the behaviour of institutional structures.

This paper uses the traditional SURE estimation approach, which does not assume a priori independence of errors across countries and allows for conventional tests for contemporaneous correlation and also provides a basis for testing behavioural restrictions across countries (such as equality of coefficients). In order to capture the possible cross-country dependence within the Franc zone, whilst keeping in line with equation 6 , this paper proceeds to estimate the long-run relationship between the REER and its fundamentals (of the form in equation 6) in a SURE model. Next, I use the coefficients obtained from the long-run SURE model, for each country, to calculate the equilibrium RER for each period $t$. Conceptually, this paper distinguishes between the 'short-run equilibrium' RER (SRER) and the 'long-run equilibrium' RER (LRER). Specifically, SRER is computed simply by applying the estimated $\hat{\beta}$ to the predetermined and actual values of the policy and exogenous variables $[F(z)]$; and LRER, by applying the long-run parameters to 'sustainable' values of the fundamentals, which have been obtained by exponentially smoothing the fundamentals. ${ }^{15}$

It is important, at this stage, to note that there may be efficiency gains by introducing dynamics into the SURE model, say by adopting the Dynamic Seemingly Unrelated Cointegrating Regressions approach (Mark, Ogaki and Sul, (2005)). However, given the number of cross-sections $(N)$ and time span $(T)$ available in our dataset, this is not a feasible option as it demands many degrees of freedom. ${ }^{16}$

\footnotetext{
Williamson, 1994; Devarajan, 1997, Baffes et al, 1999.

${ }^{14}$ Pesaran et al. (1999) discuss alternative estimation methods for dynamic panels, including the seemingly unrelated regression equation (SURE) procedure, the Mean Group (MG) approach, the Pooled Mean Group (PMG) approach, the traditional methods - fixed effects (FE), instrumental variables (IV) and generalized method of moments (GMM) - and the Bayes approach. It is noted that under particular conditions each of these methods can be used to determine the long-run parameters for estimating equilibrium RER.

${ }^{15}$ In larger samples, the Beveridge-Nelson (BN) decomposition method may be used to extract the permanent components of the fundamentals $F(z)^{p}$, however in small samples BN is highly sentitive to the underlying ARIMA specification which can be problematic. Mechanically smoothing the data is typically regarded as a more appealing approach since individual series can be smoothed substantially more, and hence may yield more economically appealing results (see Baffes et al., 1999).

${ }^{16}$ There is a trade-off between the gains of including dynamics and preventing problems associated with loss of
} 


\section{Data and empirical results}

This study uses annual data for twelve countries in the CFA Franc zone over the period 196099. Specifically, our sample includes Benin, Burkina-Faso, Cameroon, Central African Republic, Chad, Congo Republic, Côte d'Ivoire, Gabon, Mali, Niger, Senegal and Togo. Guinea Bissau and Equatorial Guinea are not included due to lack of sufficient data. The data set consists of a balanced panel of variables constructed from the World Development Indicators 2003 CD-ROM (WDI-2003) for each country as shown in Appendix B. ${ }^{17}$ Following Baffes et al. (1999), this paper uses the consumer price index $(\mathrm{CPI})$ as an index for the domestic price level $(P)$ and trade-weighted index of the wholesale price index (WPI) to measure the foreign price level $\left(P^{*}\right)$.

A list of major trading partners that account for approximately $70 \%$ of the overall trade is provided in Appendix $A$, and is based on trade volumes as reported in the IMF's Direction of Trade Statistics (DOTS) Yearbooks. The trade weights, based on the average share of overall trade with the home country, is a fixed weight assigned to each major trading partner (equal to the percentage share of its overall trade). Resource balance (RBAL), the terms of trade (TOT), fixed investment share (INVSH), government consumption (GOVCON), and openness $(\mathrm{OPN})$ are all constructed as described in Appendix $B$. The required data is obtained from the WDI-2003 CD-ROM in local currency units (CFA Francs). Where necessary all data have been re-based with 1995 as the common base year.

Various procedures have been developed in recent years to determine the presence of unit roots in the panel data context thereby taking advantage of the variations in cross-sectional dimensions as well as improving on the well-known low power of standard unit-root tests. Although ignoring significant error cross-section dependence can lead to spurious results, Pesaran (2007) also emphasizes that in cases where cross-sectional dependence is not sufficiently high, a loss of power might result if a panel unit-root test that allows for cross-sectional dependence is used. This paper first makes use of two panel unit-root tests: the standard Im, Pesaran and Shin (2003) [IPS] test, which assumes cross-sectional independence and a panel unit-root test proposed in an earlier version of Pesaran (2007) [CIPS], which allows for cross-sectional dependence (see for example Coakley et al., 2005). ${ }^{18}$ Results of tests for the level of cross-sectional

degrees of freedom. Given our sample size, either decision would have its drawbacks. The decision to estimate a static model is based on the view that it would not change the overall qualitative conclusions of the paper.

${ }^{17}$ Data on wholesale price indices (WPI) are obtained from various national data archives available on the internet e.g. Bank of Japan; Federal Statistical Office for German data; the Economic Information Office of the Federal Public Service Economy, SMEs, Self-employed and Energy of Belgium; Central Bank of Nigeria; National Statistics for Statistics and economic Studies; International Financial Statistics (IFS).

${ }^{18}$ Also known as the Augmented ADF, this is based on the t-ratio, denoted $t_{i}(N, T)$, of the least squares estimate 
dependence are reported in Table 2, which in turn informs the determination of the preferred panel unit-root test result to be applied. In each case, the null of unit-root cannot be rejected at the $5 \%$ level; in the light of this finding, a cointegration test needs to be carried out to establish stationarity of the equilibrium error term for each country. ${ }^{19}$ In theory, one possible and simple approach will be to apply the CIPS test to the residuals obtained from the SURE estimation above, thereby allowing for cross-sectional dependence while checking for stationarity of the residuals. However, at the present time, the implication of the results of these tests, reported in Table 3, remain uncertain since recent studies in the forefront of these techniques (including Pesaran, (2007)) are yet to extend to this type of residual-based tests, and to provide the appropriate the critical values. So while it is reasonable to consider a residual-based test that considers possible cross-sectional dependence, a more practical approach is to resort to a panel cointegration tests. For this purpose, I use the Pedroni (1999) framework, which proposes seven tests for investigating heterogeneous panels, and allows for heterogeneous slope coefficients, fixed effects and individual specific deterministic trends. ${ }^{20}$ Pedroni (1997) discusses the sample and size properties and finds that, on the one hand, for all seven statistics when the time span is long, the size distortions are minor and power is high. On the other hand, the evidence is more varied for shorter panels. However, Pedroni goes on to show that the Group-adf statistic and Panel-adf statistic generally perform best. Table 4 reports the results of the Pedroni tests and shows that the null of no cointegration can be rejected by the Panel pp statistic, the Panel adf statistic, the Group-pp statistic and the Group-adf statistic at the 1\% level, not by the other test statistics. Given the above discussion concerning both power properties and size distortions, the evidence supports the existence of a cointegrating relationship. Hence, a steady-state equilibrium of the form in equation 5 can be obtained through estimating equation 6 by (in our case) SURE analysis. ${ }^{21}$

of $b_{i}$ in the following cross-sectionally augmented ADF regression for each country: $\Delta q_{i t}=a_{i}+b_{i} q_{i, t-1}+c_{i} \bar{q}_{t-1}+$ $\sum_{j=0}^{p} d_{i j} \Delta \bar{q}_{t-j}+\sum_{j=1}^{p} \delta_{i j} \Delta q_{i, t-j}+e_{i t}$, where $\bar{q}_{i t}$ is the cross-sectional mean of the series $q_{i t}$. The appropriate test statistic CIPS $=\mathrm{N}^{-1} \sum_{i=1}^{N} t_{i}(N, T)$ and the critical values can be found in Pesaran (2007), Table II (a)-(c).

${ }^{19} \mathrm{In}$ this model there is no cointegration between the variables across countries of the form discussed in Banerjee et al. (2005), which may distort the results of panel unit-root tests.

${ }^{20} \mathrm{In}$ its most simple form, it takes no cointegration as the null hypothesis and uses the residuals derived from the panel version of an Engle and Granger (1987) static regression to construct the test statistic and tabulate the distributions.

${ }^{21}$ The Breusch and Pagan (1980) Lagrange Multiplier (LM) test statistic is found to be 410.73, greater than the $\chi^{2}(66)$ critical value of 95.63 , Therefore we can reject the null of no contemporaneous correlation at the $1 \%$ level of significance. Also Wald (1943) tests restricting coefficients across countries to be equal is also rejected at the $1 \%$ level of significance. 
The long-run parameters are therefore obtained from estimations of the form in equation 6 for each country by SURE, which have been reported in Table 5 along with the diagnostics. In this paper, equilibrium RER is computed as $\hat{\beta}^{\prime} F(z)^{p}$, where $\hat{\beta}$ is the vector of estimated long-run parameters and $F(z)^{p}$, the 'permanent' values of the fundamentals.

\subsection{Real exchange rate misalignment}

Figures $1-12$ depict the estimated alternative equilibriums together with the actual REER. ${ }^{22}$ The degree of real exchange rate misalignment $\left(M_{t}\right)$ in period $t$ is simply the percentage difference between the calculated equilibrium and the observed real effective exchange rate (REER) in that period. Tables 6 and 7 are directly related to figures $1-12$, and columns $2-13$ report the estimated percentage deviation of the observed REER from its equilibrium value for member states over the period 1980-99. By construction, the SRER inherently shows more variablility due to the role of the actual data in its construction, furthermore it is important to stress that the use of the dummy (D94) and specification of the model imposes REER to be equal to SRER in 1994, implying zero misalignment when considering misalignment in table 6; unless otherwise stated, our analysis is based on the misalignments reported in Table $7 .{ }^{23}$

Our discussion of the results follows the general trend of similar studies and focuses on three main periods - the period prior to 1985, 1986-93/4 and post-1994. The estimated misalignments captures the crucial occurances in the CFA Franc zone over the period.

\subsubsection{0 to the mid-1980s:}

The benefits accrued by the zone between 1960 and the mid-1980s due to rising raw material prices, when producer countries enjoyed virtual monopoly over these markets, is well known. This was helped by the the fact that CFA Franc was pegged to a weak French Franc, which was twice devalued in relation to the \$US (in 1958 and 1969), helping to counterbalance the effects of worsening CFA terms of trade and soaring international interest rates especially after 1973. Our results, represented graphically in Figures 1-12, indicate that while REER in a majority of

\footnotetext{
${ }^{22}$ It is worth noting that Figures $1-12$ can be complemented with confidence intervals based on the standard errors of the estimated parameters.

${ }^{23}$ When RER equilibrium is estimated using the Pooled Mean Group estimator (PMG) [Pesaran et al., 1999], which restricts long-run parameters to be the same across countries, I found the equilibrium showed significantly less variability compared to the method used in this current version of the paper. However, as noted by the authors, the PMG estimator is designed for applications in which $N$ and $T$ are approximately the same order of magnitude - which is not so in our case. I am particularly grateful an anonymous referee for pointing this out in an earlier version of this paper.
} 
countries were not misaligned prior to 1969, the 1969 devaluation of the French Franc vis-à-vis the $\$$ US resulted in a real devaluation of the CFA Franc - a tendency that continued until 1974. Post-1974, the underlying susceptibility of these economies to these external shocks, including the gradual decline in raw materials prices (in 1976) begin to bite and the the observed REER appreciated significantly. However, despite some bouts of real overvaluation, most member states are known to have maintained a steady and positive economic performance. ${ }^{24}$

\subsubsection{5 to $1993 / 4$ :}

Most member states began to experience significant and rapid REER appreciation - the effects of lax adherance to the zone's monerary and fiscal policies, real appreciation of the French Franc against the $\$ \mathrm{US}$, and real depreciation on the part of several key export competitors within subSaharan Africa. ${ }^{25}$ This period reveals significant differences among member states. The larger economies - Cameroon, Côte d'Ivoire and Senegal - are most affected and experience the most appreciation in their REER: about 29\% in Côte d'Ivoire, $11 \%$ in Cameroon and $7 \%$ in Senegal between 1985 to 1993.

On average Benin, Mali, Niger and Togo were virtually in equilibrium over the period, whiles Burkina Faso, and the Congo show only mild misalignment. The most misaligned group of countries include Cameroon, Central African Republic, Chad, Côte d'Ivoire and Senegal. Over this period, the estimated average overvaluation (based on Table 7) is significantly higher in these three economies compared to other member states. The average overvaluation in Côte d'Ivoire over the period is found to be $6.8 \%, 5.8 \%$ in Cameroon and $5.0 \%$ in Senegal; above the relatively lower overvaluation esimated for other member states which average $1.1 \%$. Using the SRER (based on Table 6), overvaluation in Côte d'Ivoire, Cameroon and Senegal are $5.6 \%, 5.3 \%$ and $4.7 \%$ respectively. Noticeably, the estimated misalignments in this paper are significantly lower than estimates reported in other studies which do not account for crosssectional dependence between member states. ${ }^{26}$

The ill-effects of the CFA Franc overvaluation included an increase in poverty levels, inability

\footnotetext{
${ }^{24}$ From 1975 to 1985 , average annual real GDP growth in the CFA Franc zone rose to $4.6 \%$ with an annual inflation rate of $11.2 \%$ versus $1.4 \%$ and $17.8 \%$ respectively for the other sub-Saharan countries. See Elbadawi and Majd, (1996) for a more extensive discussion.

${ }^{25}$ This was particularly the case in the larger economies of Cameroon, Côte d'Ivoire and Senegal which had the highest inflation rates.

${ }^{26}$ For Example Devarajan (1997) finds a 36\% overvaluation in Côte d'Ivoire in 1993 and 9\% in 1994. Baffes et al. (1999) find overvaluation to be about $35 \%$ by 1988. A possible explanation for such a huge difference may be that the extent of bias introduced by neglecting cross-country interdependence within the Franc zone has been grossly underestimated in these studies.
} 
of private sector to repay debts, public sector arrears, and speculation leading to capital flight (see Devarajan and Hinkle, 1994). By July of 1993, the estimated outgoing capital flows was in the region of 850 million French Francs per month, up from the reported 600 million in 1988. ${ }^{27}$ With nominal devaluation not available as a policy instrument at the country level, adjustment by deflating the economy was slow, costly, and politically difficult. Attempts at country-level mock-devaluations by both Côte d'Ivoire and Senegal with export subsidies and increases in import tariff rates failed largely due to administration difficulties, and rigid labour laws that kept wages high (see Clément, 1994 and Foroutan, 1997). Figures 1-12 indicate that the $100 \%$ devaluation in 1994, aimed at halting the ill-effects of REER overvaluation brought the economies of member states in line with their SRER. However, by considering the LRER, this study finds that the devaluation rendered the observed REER in Benin, Chad, the Congo, Gabon, Niger and Togo significantly undervalued relative to the equilibrium. Our results also indicate mild undervaluation in Burkina Faso, Cameroon, Central African Republic, Mali and Senegal. In fact, the evidence suggests that only Côte d'Ivoire, which commands about $40 \%$ of the zone's GDP, settles into equilibrium based on both the estimate of SRER and LRER.

\subsubsection{4 to 1999 :}

It has been well-documented that both GDP and inflation responded favourably in the period following the devaluation, especially as there was an associated improvement in the terms of trade, increases in aid packages, some wage moderation and debt repayment rescheduling. Up until 1997, Figures $1-12$ show that most countries in the Franc zone were either only mildly undervalued or virtually in equilibrium. However, by this time the largest economy in the zone, Côte d'Ivoire had again become overvalued by 6.1\% (comparable to pre-1994 levels). By 1998 the outlook does not look very promising as Cameroon and Senegal also follow suit, a pattern which is seen to continue in 1999.

\section{Concluding remarks}

This study analyzes real effective exchange rate misalignment across 12 countries of the CFA Franc zone and makes a number of new contributions to the existing literature. Unlike much of the previous research, this study is not restricted to analysis of the period before the 1994

\footnotetext{
${ }^{27}$ Source: Revue Tiers Monde, No. 143, July - September, (1995).
} 
collective devaluation. Secondly, the estimation methods adopted in this paper allow for the effects of cross-country dependence. Finally, this paper explicitly distinguishes between shortrun and long-run misalignments in the REER. In particular, this paper accounts for crosssectional dependence between the cross-sections and estimates equilibrium REER in a SURE model that accounts for cross-country error covariances over the period 1960-99.

Specifically, in addressing the questions posed in Section 1 of this paper, our results cannot support the view that member-states were systematically overvalued throughout the 1970s and 1980s. Whiles there is some evidence of overvaluation in the late 1980s, the results are mixed and do not support this view for the 1970s. Secondly, there are significant differences between the estimated REER misalignment across individual member-states. On average, our estimates are (in value terms) significantly smaller than those obtained in similar studies that have not accounted for cross-sectional dependence. By 1993, the highest overvaluation levels can be seen in the three largest economies of the zone: Cameroon (5.8\%), Côte d'Ivoire (6.8\%) and Senegal (5.0\%). While these estimates of misalignement may not seem exceptionally large, an analysis of the rate of appreciation in the REER in these countries relative to the equilibrium value was rather staggering over the few years prior to 1994. Combined with exogenous real devaluations of export competitors in the sub-region, speculation regarding devaluation was rife and I have discussed, albeit briefly, some of the macroeconomic ill-effects during this critical period. I have also shown that some of the smaller economies were hardly misaligned and the uniform $100 \%$ devaluation resulted in significant undervaluation (relative to the LRER) in most member-states. Interestingly, only the largest economy in the zone Côte d'Ivoire was found to be in equilibrium in 1994 (with respect to both SRER and LRER) as a result of the devaluation. Thirdly, in the period after the devaluation, I have shown that the respite offered by the uniform devaluation was short-lived because by 1998 the three largest economies of the Franc zone again show all the signs of reverting to their pre-devaluation overvaluation levels. Overall, this paper has found some evidence of stark differences across member-states, and suggest that the increasing overvaluation in the three largest economies may have played a major role in opting for a uniform devaluation in 1994. A major contribution of this paper may be that it draws attention to the importance of accounting for cross-country interdependence when estimating REER misalignment acoss countries and particularly in monetary unions such as the Franc zone.

Using the relatively simple single-equation estimation, this study has accounted for the 
effects of cross-country interdependence in estimating REER misalignment within the Franc zone, thereby providing a more complete analysis. Furthermore, Wald coefficient restriction tests suggest that an estimation method that constrains long-run parameters to be equal across countries, such as the Pooled Mean Group approach (Pesaran et al., 1999) will be inappropriate for estimating REER misalignment in the Franc zone.

While only briefly discussed in this paper, the state of misalignment across the Franc zone in 1999 and factors such as the recent unrests in Côte d'Ivoire, falling export prices of agricultural commodities, recent rises in the strength of the Euro as well as rising world oil prices suggest difficult times ahead for the Franc zone if the current parity is to be maintained, and presents an interesting extension to this study. 


\section{A Main Trading Partners}

\begin{tabular}{|c|c|}
\hline Country & Main Trading Partners ${ }^{a}$ \\
\hline \multirow[t]{2}{*}{ Benin } & Côte d'Ivoire (8.3), China (11.7), France (38.8), Germany (7.4), \\
\hline & Japan (4.3), Netherlands (10.0), UK (11.4), USA (8.1) \\
\hline \multirow[t]{2}{*}{ Burkina Faso } & Côte d'Ivoire (34.1), France (42.1), Germany (4.2), \\
\hline & Japan (5.5), Nigeria (5.9), U.K. (2.4), USA (5.8) \\
\hline \multirow[t]{2}{*}{ Cameroon } & France (50.6), Germany (11.4), Japan (8.0), \\
\hline & Nigeria (13.9), UK (5.2), USA (1.0) \\
\hline \multirow[t]{2}{*}{ Central African Rep. } & Cameroon (12.5), Côte d'Ivoire (1.4), France (64.2), \\
\hline & Germany (5.1), Japan (11.4), UK (1.4), USA (3.9) \\
\hline \multirow[t]{2}{*}{ Chad } & Cameroon (10.6), France (62.2), Germany (3.4), \\
\hline & Japan (2.5),Nigeria (11.4), UK (3.0), USA (6.9) \\
\hline \multirow[t]{2}{*}{ Republic of Congo } & Côte d'Ivoire (2.4), France (65.6), Japan (3.4), \\
\hline & Germany (4.8), UK (7.3), USA (16.6) \\
\hline \multirow[t]{2}{*}{ Côte d'Ivoire } & Belgium (4.6), France (43.3), Germany (6.5), \\
\hline & Japan (5.7), Nigeria (27.5), UK (4.1), USA (8.2) \\
\hline \multirow[t]{2}{*}{ Gabon } & Côte d'Ivoire (3.2), France (73.7), Germany (3.6), \\
\hline & Japan (5.5), UK (5.4), USA (8.7) \\
\hline \multirow[t]{2}{*}{ Mali } & China (4.0), Côte d'Ivoire (38.6), France (36.8), \\
\hline & Germany (6.4), Japan (2.3), UK (6.0), USA (5.7) \\
\hline \multirow[t]{2}{*}{ Niger } & China (2.5), Côte d'Ivoire (18.5), France (44.3), Germany (7.2) \\
\hline & Japan (6.1), Netherlands (4.8), UK (6.5), USA (10.1) \\
\hline \multirow[t]{2}{*}{ Senegal } & Belgium (4.8), Côte d'Ivoire (5.0), France (52.0), Germany (6.8), \\
\hline & Japan (5.0), Nigeria (14.1), UK (3.5), USA (8.8) \\
\hline \multirow[t]{2}{*}{ Togo } & China (3.1), Côte d'Ivoire (15.7), France (47.2), Germany (10.6), \\
\hline & Ghana (3.4), Japan (6.5), UK (6.6), USA (6.9) \\
\hline
\end{tabular}

\footnotetext{
${ }^{a}$ Source: Direction of Trade Statistics Yearbooks. Main Trading Partners' trade volumes make up about $70 \%$ of overall trade with the home country. Figures in parentheses refer to average percentage share of overall trade, and these have been normalised to add to $100 \%$. We note here that these trade shares have been used to compute the trade weights $w_{j}=\frac{\text { average percentage share of overall trade }}{100}$.
} 


\section{B Data Description}

1. Real Effective Exchange Rate $(R E E R)$ - The ratio of domestic price level (CPI) to the trade-weighted index of foreign price level (WPI) each expressed in CFA Francs. This is calculated as a geometric average across home country i's $n$ largest trading partners that make up about $70 \%$ of total trade. The trade shares are used as weights $\left(w_{j}\right)$ and have been normalised to sum to unity.

$$
R E E R_{t_{i}}=\prod_{j=1}^{n} R E R_{t_{i}}^{w_{j}} .
$$

2. Resource Balance to GDP Ratio $(R B A L)$ - Value of exports $(E X P K)$ minus the value of Imports $(I M P K)$, as a ratio of the gross domestic product $(G D P)$ all at constant prices and in local currency units (CFA Francs).

$$
R B A L=\frac{(E X P K-I M P K)}{G D P}
$$

3. Investment Share $(I N V S H)$ - Ratio of the gross fixed capital formation $(G F C F K)$ to gross domestic product $(G D P)$ also at constant prices and in local currency units (CFA Francs).

$$
I N V S H=\frac{G F C F K}{G D P}
$$

4. Openness $(O P N)$ - Ratio of the sum of imports and exports of goods and services to $G D P$, all at constant prices and all in local currency units (CFA Francs).

$$
O P N=\frac{(E X P K+I M P K)}{G D P}
$$

5. The Terms of Trade $(T O T)$ - Ratio of the export price deflator $\left(P_{X}\right)$ to the import price deflator $\left(P_{M}\right)$ both at constant prices and in local currency units (CFA Francs).

$$
T O T=\frac{P_{X}}{P_{M}}
$$

6. Government Consumption (GOVCON) - Ratio of Government consumption as a share 
of $G D P$, both at constant prices and in local currency units (CFA Francs).

$$
G O V C O N=\frac{G O V K}{G D P}
$$

Table 1: Hausmann tests for endogeneity of RBAL and GOVCON

\begin{tabular}{lcc}
\hline \hline & $1960-1999(\mathrm{~T}=40)$ \\
\hline \hline & RBAL & GOVCON \\
\cline { 2 - 3 } Ben & $1.11(0.98)$ & $0.65(0.99)$ \\
Bfa & $0.23(0.99)$ & $0.35(0.99)$ \\
Cam & $1.46(0.96)$ & $1.36(0.96)$ \\
CAR & $1.75(0.94)$ & $4.38(0.62)$ \\
Chd & $2.22(0.89)$ & $2.11(0.91)$ \\
Con & $1.11(0.98)$ & $11.04(0.08)$ \\
Civ & $2.62(0.85)$ & $2.28(0.89)$ \\
Gab & $7.40(0.28)$ & $1.14(0.97)$ \\
Mal & $2.32(0.88)$ & $2.27(0.89)$ \\
Nig & $0.03(0.99)$ & $5.00(0.54)$ \\
Sen & $7.12(0.31)$ & $11.44(0.07)$ \\
Tog & $3.90(0.69)$ & $6.31(0.38)$ \\
\hline
\end{tabular}

Notes: Figures in table represent the Hausmann test statistic and figures in parentheses are the respective $p$-values, with 6 d.f. i.e. $\chi^{2}(6)$ using two lags of RBAL and GOVCON as instruments, both of which are confirmed as valid instruments based on the Sargan test statistic $\left(\mathrm{NR}^{2}\right)$. The critical value at $5 \%$ level of significance is 12.59 , hence the null of exogeneity of RBAL and GOVCON cannot be rejected at the $5 \%$ level. 
Table 2: Cross-section correlations of the errors in the $\mathrm{ADF}(\mathrm{p})$ regressions for individual series across countries and panel unit-root test statistics $(\mathrm{N}=12)$

\begin{tabular}{lcccc}
\hline \hline \multicolumn{5}{c}{$1960-1999(\mathrm{~T}=40)$} \\
\hline \hline $\ln e$ & $\overline{\hat{\rho}}$ & $C S D$ & $I P S$ & $C I P S$ \\
\cline { 2 - 5 }$R B A L$ & 0.557 & 28.62 & $\mathbf{- 1 . 3 5 4}$ & $\mathbf{- 1 . 6 8 3}$ \\
$\ln O P N$ & 0.068 & 3.54 & $\mathbf{- 1 . 8 2 1}$ & $\mathbf{- 2 . 5 6 3}$ \\
$\ln I N V S H$ & 0.031 & 1.59 & $\mathbf{- 1 . 4 4 4}$ & -2.215 \\
$\ln T O T$ & 0.032 & 1.63 & $\mathbf{- 1 . 4 6 3}$ & -2.924 \\
$\ln G O V C O N$ & 0.095 & 4.89 & $\mathbf{- 1 . 8 5 2}$ & -2.428 \\
\hline \hline & 0.013 & 0.68 & $\mathbf{- 1 . 7 1 4}$ & -2.093 \\
\hline \hline
\end{tabular}

Notes: Specifically $\overline{\hat{\rho}}=\left(\frac{2}{N(N-1)}\right) \sum_{i=1}^{N-1} \sum_{J=i+1}^{N} \widehat{\rho}_{i j}$, where $\widehat{\rho}_{i j}$ are the computed pairwise cross-section correlation coefficients of the residuals from individual $\operatorname{ADF}(\mathrm{p})$ regressions. Number of lags included $(p)$ for each Individual country is determined by the modified Schwartz Criterion (MSIC). Also CSD $=\left[\frac{T N(N-1)}{2}\right]^{0.5} \overline{\hat{\rho}}$. Under the null hypothesis of zero cross-sectional dependence, CSD is asymptotically distributed as $N(0,1)$. CIPS critical values for $\mathrm{N}=12$ and $\mathrm{T}=40$ are $-2.50,-2.29$ and -2.18 at the $1 \%, 5 \%$ and $10 \%$ level of significance respectively (see Pesaran, 2007 Table II (b). Critical values for IPS are $-2.10,-1.94,-1.85$ respectively for $1 \%$, $5 \%$ and $10 \%$ (Im et al., 2003, Table 2). To avoid loss of power, the CIPS test statistic is preferred only when evidence of cross-sectional dependence is significant in both $C S D$ and $\overline{\hat{\rho}}$. Entries in bold indicate the preferred panel unit-root test statistic.

Table 3: Panel unit-root test results (on SURE residuals)

\begin{tabular}{ccccccc}
\hline \hline & Ben & Bfa & Cam & CAR & Civ & Chd \\
\hline \hline$t_{i}(N, T)$ & -6.02 & -3.71 & -2.52 & -5.88 & -1.68 & -2.79 \\
& Con & Gab & Mal & Nig & Sen & Tog \\
\hline \hline$t_{i}(N, T)$ & -1.75 & -1.87 & -3.53 & -5.00 & -0.95 & -3.88 \\
CIPS $(N, T)$ & \multicolumn{5}{c}{-3.30} \\
\hline
\end{tabular}

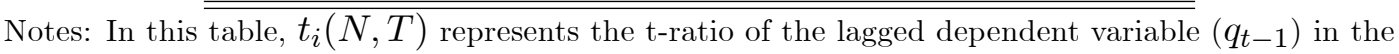
cross-sectionally augmented ADF regression for country $i$ of the form $\Delta q_{i t}=a_{i}+b_{i} q_{i, t-1}+c_{i} \bar{q}_{t-1}+\sum_{j=0}^{p} d_{i j} \Delta \bar{q}_{t-j}+\sum_{j=1}^{p} \delta_{i j} \Delta q_{i, t-j}+e_{i t}$, where $q_{t}$ is representing the residuals obtained from equation 6, again using the Modified Schwartz Information Criteria (MSIC) to select the appropriate lag-length $p$. CIPS, the appropriate panel test statistic, is a computed as

$$
C I P S=N^{-1} \sum_{i=1}^{N} t_{i}(N, T)
$$


Table 4: Pedroni Panel Cointegration Test

\begin{tabular}{|c|c|c|c|c|c|c|}
\hline $\begin{array}{c}\text { Panel } \\
\text {-statistic }\end{array}$ & $\begin{array}{c}\text { Panel } \\
\rho \text {-statistic }\end{array}$ & $\begin{array}{c}\text { Panel } \\
\text { pp-statistic }\end{array}$ & $\begin{array}{c}\text { Panel } \\
\text { adf-statistic }\end{array}$ & $\begin{array}{c}\text { Group } \\
\rho \text {-statistic }\end{array}$ & $\begin{array}{c}\text { Group } \\
\text { pp-statistic }\end{array}$ & $\begin{array}{c}\text { Group } \\
\text { adf-statistic }\end{array}$ \\
\hline-0.8098 & 0.2276 & $-2.9671^{*}$ & $-3.1109^{*}$ & 1.3241 & $-2.9327^{*}$ & $-2.9685^{*}$ \\
\hline
\end{tabular}

Notes: Critical values at 5\% (1\%) level for panel v-statistic and the other six statistics are 1.645 and -1.645

(1.96 and -1.96) respectively. ${ }^{* * *},{ }^{* * *}$ indicates rejection of the null of no cointegration at $1 \%, 5 \%$ and $10 \%$ respectively. The formulae for computing these statistics can be found in Table 1 of Pedroni (1999). Panel $\nu$ is

a nonparametric variance ratio statistic. Panel $\rho$ and Panel pp are analogous to the nonparametric

Phillips-Perron $p$ - and $t$-statistics respectively. Panel-adf is a parametric statistic based on the augmented Dickey-Fuller (ADF) statistic. Group $\rho$ is analogous to the Phillips-Perron $p$-statistic. Group-pp and Group-adf are analogous to the Phillips-Perron $t$-statistic and the ADF statistic respectively.

Figures 1-12: Time series plots of REER, SRER and LRER for individual member-states.

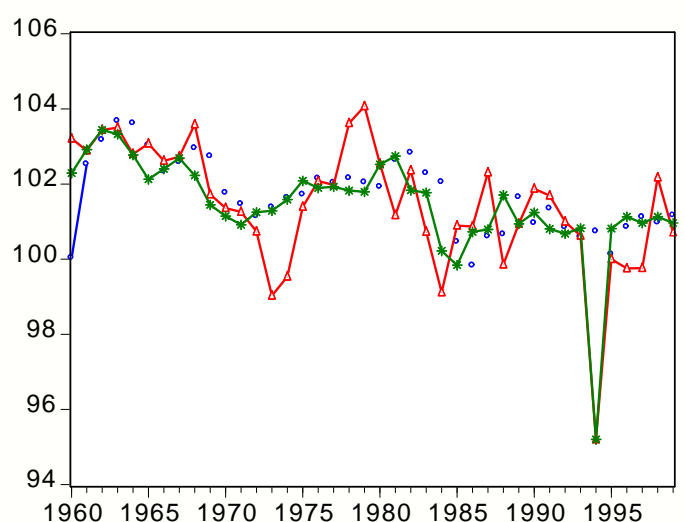

$\multimap$ LRER $\multimap$ REER $\rightarrow$ SRER

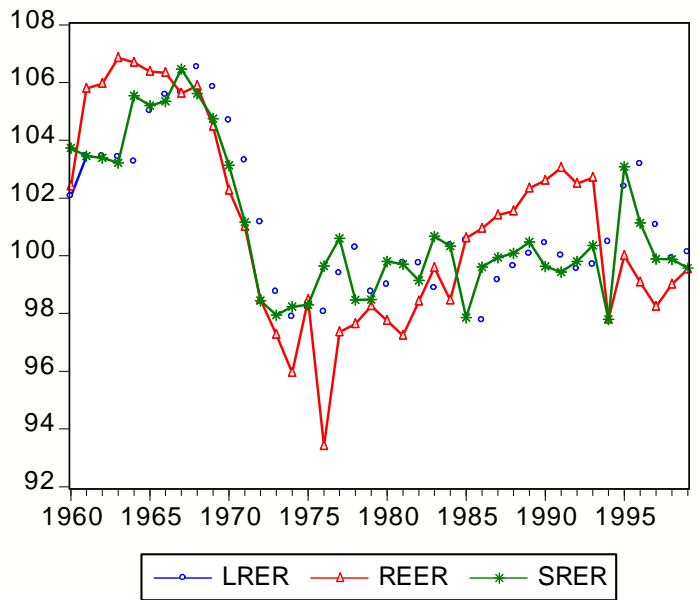

Fig. 2. The REER for Burkina Faso, 1960-99 (1995 REER = 100) 
Table 5: SURE regression estimates and diagnostic statistics

\begin{tabular}{|c|c|c|c|c|c|c|c|c|c|c|}
\hline \multicolumn{11}{|c|}{$1960-1999(\mathrm{~T}=40)$} \\
\hline \multirow{3}{*}{ Ben } & $C$ & $R B A L$ & $\ln I N V S H$ & $\bar{l} \ln G O V C O N$ & 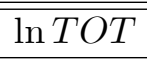 & $\ln O P N$ & D94 & 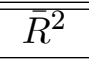 & $\overline{D W}$ & S.E. \\
\hline & $4.36^{*}$ & $-0.96^{*}$ & -0.01 & -0.001 & -0.07 & $-0.17^{*}$ & $-0.22^{*}$ & 0.56 & 1.48 & 0.05 \\
\hline & $(0.15)$ & $(0.17)$ & $(0.02)$ & $(0.04)$ & $(0.05)$ & $(0.03)$ & $(0.04)$ & & & \\
\hline \multirow[t]{2}{*}{$B f a$} & $3.73^{*}$ & -0.56 & $-0.28^{*}$ & -0.02 & $0.13^{* *}$ & $-0.25^{* * *}$ & $-0.22^{* *}$ & 0.55 & 1.82 & 0.10 \\
\hline & $(0.22)$ & $(0.52)$ & $(0.05)$ & $(0.07)$ & $(0.06)$ & $(0.14)$ & $(0.09)$ & & & \\
\hline \multirow[t]{2}{*}{ Cam } & $5.65^{*}$ & $1.54^{*}$ & $0.03^{* * *}$ & $0.42^{*}$ & 0.11 & $0.49^{*}$ & -0.05 & 0.52 & 1.61 & 0.20 \\
\hline & $(0.33)$ & $(0.40)$ & $(0.06)$ & $(0.14)$ & $(0.13)$ & $(0.15)$ & $(0.18)$ & & & \\
\hline \multirow[t]{2}{*}{$C A R$} & $3.82^{*}$ & 0.23 & $0.17^{*}$ & $-0.71^{*}$ & $0.35^{*}$ & $0.23^{* * *}$ & -0.12 & 0.63 & 1.59 & 0.13 \\
\hline & $(0.24)$ & $(0.60)$ & $(0.06)$ & $(0.08)$ & $(0.09)$ & $(0.13)$ & $(0.13)$ & & & \\
\hline \multirow[t]{2}{*}{ Chd } & $3.08^{*}$ & -1.62 & $-0.35^{* *}$ & $-0.44^{* *}$ & $-0.85^{*}$ & $0.62^{* * *}$ & 0.18 & 0.48 & 1.94 & 0.09 \\
\hline & $(0.47)$ & $(-1.18)$ & $(0.15)$ & $(0.19)$ & $(0.23)$ & $(0.33)$ & $(0.28)$ & & & \\
\hline \multirow[t]{2}{*}{ Con } & $5.31^{*}$ & $1.15^{*}$ & -0.004 & $0.21^{*}$ & $0.32^{*}$ & 0.07 & $-0.15^{* * *}$ & 0.37 & 1.53 & 0.13 \\
\hline & $(0.09)$ & $(0.23)$ & $(0.05)$ & $(0.06)$ & $(0.08)$ & $(0.11)$ & $(0.08)$ & & & \\
\hline \multirow[t]{2}{*}{ Civ } & $5.12^{*}$ & -0.007 & $0.21^{*}$ & 0.01 & 0.02 & 0.20 & $-0.50^{*}$ & 0.55 & 1.50 & 0.31 \\
\hline & $(0.20)$ & $(0.10)$ & $(0.06)$ & $(0.13)$ & $(0.08)$ & $(0.15)$ & $(0.13)$ & & & \\
\hline \multirow[t]{2}{*}{$G a b$} & $4.25^{*}$ & $-1.06^{*}$ & $-0.22^{*}$ & $-0.24^{* *}$ & 0.05 & $0.25^{* *}$ & $-0.22^{* * *}$ & 0.52 & 1.69 & 0.13 \\
\hline & $(0.21)$ & $(0.20)$ & $(0.07)$ & $(0.09)$ & $(0.06)$ & $(0.09)$ & $(0.16)$ & & & \\
\hline \multirow[t]{2}{*}{ Mal } & $4.96^{*}$ & 0.06 & $0.13^{* * *}$ & $0.05^{* * *}$ & $0.27^{*}$ & $0.18^{*}$ & -0.03 & 0.75 & 1.26 & 0.06 \\
\hline & $(0.16)$ & $(0.20)$ & & $(0.03)$ & $(0.06)$ & & $(0.05)$ & & & \\
\hline \multirow[t]{2}{*}{$N i g$} & $4.99^{*}$ & 0.39 & $0.06^{* *}$ & -0.05 & $0.30^{*}$ & $0.19^{*}$ & $-0.26^{*}$ & 0.70 & 1.93 & 0.08 \\
\hline & (0.14) & $(0.24)$ & $(0.02)$ & $(0.07)$ & $(0.06)$ & $(0.05)$ & $(0.08)$ & & & \\
\hline \multirow[t]{2}{*}{ Sen } & $5.27^{*}$ & $1.84^{* *}$ & -0.08 & $0.58^{* *}$ & 0.19 & $-0.49^{*}$ & -0.09 & 0.25 & 1.50 & 0.17 \\
\hline & $(0.76)$ & $(0.75)$ & $(0.13)$ & $(0.26)$ & $(0.15)$ & $(0.18)$ & $(0.15)$ & & & \\
\hline \multirow[t]{2}{*}{ Tog } & $4.81^{*}$ & $-0.24^{*}$ & 0.02 & $0.07^{* * *}$ & 0.02 & $-0.08^{* *}$ & $-0.24^{*}$ & 0.54 & 1.22 & 0.05 \\
\hline & (0.07) & $(0.08)$ & $(0.02)$ & $(0.04)$ & $(0.03)$ & $(0.04)$ & $(0.05)$ & & & \\
\hline
\end{tabular}

Notes: Figures in table represent the SURE estimates, and the figures in parentheses are the standard errors. $C$ refers to the intercept; $\bar{R}^{2}$ to the Adjusted $R^{2} ; D W$ is the Durbin-Watson statistic and $S E$ refers to the standard error of the regression. ${ }^{*},{ }^{* *},{ }^{* *}$ indicates statistical significance at $1 \%, 5 \%$ and $10 \%$ level of significance respectively. 
Table 6: Estimated overvaluation in the REER based on SRER: 1980-99

\begin{tabular}{ccccccccccccc}
\hline \hline \multicolumn{1}{c}{ Ben } & Bfa & Cam & CAR & Civ & Chd & Con & Gab & Mal & Nig & Sen & Tog \\
\hline \hline 1980 & 0.0 & -2.1 & -4.3 & 0.8 & -7.4 & -0.5 & 2.7 & 1.9 & -2.7 & -1.4 & -4.1 & -0.3 \\
1981 & -1.5 & -2.5 & -4.9 & 0.6 & -9.8 & -1.5 & 2.8 & -2.9 & -1.8 & 1.0 & -4.1 & 0.1 \\
1982 & 0.5 & -0.7 & -3.0 & 0.0 & -9.8 & 1.1 & 1.4 & -0.3 & -0.8 & 1.1 & -4.5 & 0.4 \\
1983 & -1.0 & -1.1 & -4.0 & -1.3 & -10.3 & -3.2 & 0.9 & -1.9 & 0.6 & -2.0 & -4.9 & 0.8 \\
1984 & -1.1 & -1.9 & -7.8 & -4.0 & -14.5 & -2.5 & 1.5 & -1.1 & 0.0 & -0.5 & -4.1 & -1.7 \\
1985 & 1.0 & 2.7 & -3.2 & 3.2 & -4.5 & 1.8 & 3.4 & 0.5 & -0.8 & 1.4 & 0.4 & -0.3 \\
1986 & 0.1 & 1.3 & 3.5 & 2.8 & 4.4 & 0.4 & -0.8 & 1.8 & 0.4 & 1.3 & 3.4 & 0.6 \\
1987 & 1.5 & 1.4 & 10.0 & 2.8 & 6.8 & 0.3 & 2.6 & 4.2 & 0.2 & 0.5 & 5.1 & 1.5 \\
1988 & -1.9 & 1.4 & 7.1 & 1.7 & 5.7 & 0.6 & 0.3 & 2.4 & -0.9 & -1.1 & 3.3 & 0.4 \\
1989 & 0.0 & 1.8 & 4.5 & 2.2 & 6.5 & 1.5 & 3.7 & 2.9 & -0.6 & 0.0 & 4.2 & 0.4 \\
1990 & 0.6 & 2.9 & 4.3 & 4.4 & 2.8 & 3.8 & 2.4 & 4.9 & -0.1 & 1.7 & 5.2 & 0.2 \\
1991 & 0.9 & 3.5 & 3.0 & 3.2 & 3.1 & 3.1 & 1.3 & 2.8 & 0.5 & 0.6 & 4.7 & 0.3 \\
1992 & 0.3 & 2.6 & 3.4 & 3.6 & 6.4 & 1.2 & -0.2 & 0.0 & 0.7 & -1.8 & 5.8 & -0.5 \\
1993 & -0.2 & 2.3 & 6.5 & 2.8 & 9.2 & 0.9 & -2.5 & 0.4 & 1.3 & -2.4 & 5.9 & -0.4 \\
1994 & 0.0 & 0.0 & 0.0 & 0.0 & 0.0 & 0.0 & 0.0 & 0.0 & 0.0 & 0.0 & 0.0 & 0.0 \\
1995 & -0.8 & -3.1 & 2.4 & -1.0 & 8.8 & -1.9 & -3.8 & -0.7 & 3.0 & -2.1 & 1.7 & -0.5 \\
1996 & -1.4 & -2.1 & 0.1 & -0.5 & 7.0 & -2.9 & -5.0 & -3.2 & 1.6 & -2.7 & 0.7 & -1.1 \\
1997 & -1.2 & -1.7 & 1.1 & -2.5 & 6.1 & 1.6 & -3.6 & -3.5 & 0.1 & -2.5 & -0.2 & -0.8 \\
1998 & 1.0 & -0.9 & 1.4 & -1.2 & 5.6 & 0.5 & -7.5 & -2.5 & 0.6 & -0.3 & 2.1 & -0.6 \\
1999 & -0.3 & 0.0 & 2.5 & -1.4 & 13.4 & 0.9 & -5.0 & -4.0 & -0.5 & -1.7 & 5.3 & -1.8 \\
\hline \hline
\end{tabular}

Notes: Misalignment is computed as (SRER-Actual REER)*100/(Actual REER). A negative (positive) entry represents overvaluation (undervaluation) of the CFA Franc. All entries are computed from estimates of the $S R E R$ and the actual $R E E R$, where $S R E R$ is the fitted $R E E R$ values obtained directly from the regression based on equation 6 . 
Table 7: Estimated overvaluation in the REER based on LRER ('Sustainable' REER): 1980-99

\begin{tabular}{ccccccccccccc}
\hline \hline & Ben & Bfa & Cam & CAR & Civ & Chd & Con & Gab & Mal & Nig & Sen & Tog \\
\hline \hline 1980 & 0.6 & -1.3 & 0.1 & 2.1 & 7.2 & -1.0 & 3.9 & 2.3 & -1.5 & 0.0 & -4.1 & -2.0 \\
1981 & -1.4 & -2.6 & -3.8 & 0.9 & -5.8 & -1.4 & 4.5 & 0.9 & -1.9 & -0.4 & -6.0 & -0.1 \\
1982 & -0.5 & -1.3 & -5.2 & 2.7 & -9.3 & -1.9 & 1.8 & -1.8 & -0.2 & 1.0 & -3.9 & 0.3 \\
1983 & -1.5 & 0.7 & -2.2 & -0.1 & -10.6 & -1.0 & 0.1 & -0.8 & 0.6 & -2.1 & -3.1 & 0.5 \\
1984 & -3.0 & -1.9 & -3.0 & -3.3 & -11.2 & -0.8 & 0.8 & -3.1 & 0.6 & -2.5 & -3.5 & -1.6 \\
1985 & 0.4 & 0.1 & -1.8 & 2.8 & -8.4 & -2.9 & 2.9 & 0.7 & 1.3 & 1.5 & 0.3 & -0.3 \\
1986 & 1.0 & 3.2 & 2.4 & 2.3 & 3.8 & 0.2 & -2.7 & 2.3 & 0.6 & 1.6 & 4.2 & 1.2 \\
1987 & 1.7 & 2.2 & 7.6 & 2.4 & 11.0 & 1.4 & 0.9 & 1.7 & 0.8 & 0.7 & 5.4 & 1.3 \\
1988 & -0.8 & 1.9 & 7.1 & 3.1 & 6.7 & 1.3 & -0.1 & 1.7 & -0.9 & -1.9 & 3.8 & -0.1 \\
1989 & -0.7 & 2.2 & 8.5 & 3.0 & 8.1 & 1.8 & 3.1 & 3.6 & -0.7 & -1.2 & 5.4 & 0.6 \\
1990 & 0.9 & 2.1 & 7.5 & 2.7 & 7.3 & 2.5 & 3.2 & 4.3 & 0.9 & 0.2 & 4.7 & 0.7 \\
1991 & 0.3 & 3.0 & 5.3 & 3.8 & 4.1 & 4.3 & 1.5 & 1.9 & 0.5 & -0.6 & 4.8 & -0.1 \\
1992 & 0.1 & 2.9 & 4.0 & 3.1 & 5.8 & 0.9 & 0.0 & -0.3 & 0.0 & -2.1 & 5.7 & -0.5 \\
1993 & 0.0 & 2.9 & 4.0 & 2.8 & 7.9 & 1.0 & -0.8 & -0.1 & 0.9 & -2.5 & 6.1 & -1.1 \\
1994 & -5.8 & -2.7 & -1.9 & -1.4 & -0.2 & -5.3 & -10.7 & -7.5 & -2.2 & -7.8 & -1.2 & -5.4 \\
1995 & -0.1 & -2.4 & 1.8 & 0.4 & 8.6 & -0.5 & -4.6 & -1.1 & 3.1 & -2.2 & 2.0 & -0.9 \\
1996 & -1.1 & -4.1 & 1.1 & -2.7 & 7.5 & -1.3 & -4.3 & -2.8 & 2.0 & -2.7 & 0.9 & -1.5 \\
1997 & -1.3 & -2.9 & -0.3 & -2.0 & 6.1 & -2.7 & -4.8 & -3.0 & 0.5 & -2.8 & 0.5 & -0.5 \\
1998 & 1.2 & -0.9 & 1.7 & -2.5 & 7.9 & -0.2 & -7.7 & -2.9 & 0.5 & 0.1 & 1.3 & 0.0 \\
1999 & -0.4 & -0.6 & 3.7 & -2.2 & 11.7 & 1.9 & -4.0 & -4.0 & -1.0 & -2.6 & 5.0 & -1.9 \\
\hline \hline
\end{tabular}

Notes: Misalignment is computed as (LRER-Actual REER)*100/(Actual REER). A negative (positive) entry represents overvaluation (undervaluation) of the CFA Franc. All entries are computed from estimates of the $L R E R$ and the actual $R E E R$, where $L R E R$ is defined as the fitted $R E E R$ with all fundamentals replaced by 'sustainable' values obtained through exponential smoothing methods. 


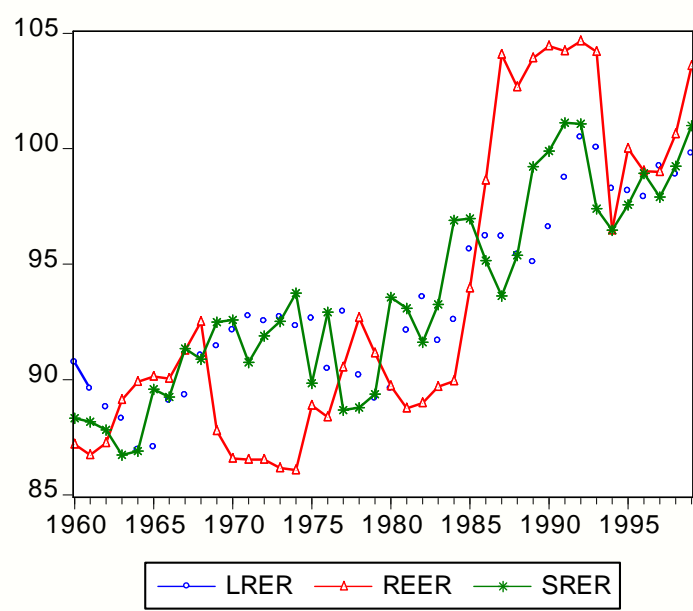

Fig. 3. The REER for Cameroon, 1960-99 $(1995 R E E R=100)$

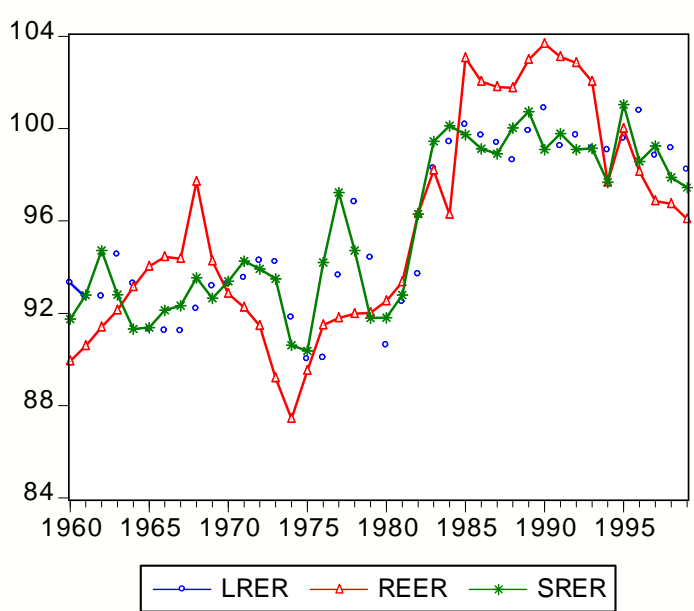

Fig. 4. The REER for Central African Republic, 1960-99 (1995 REER=100) 


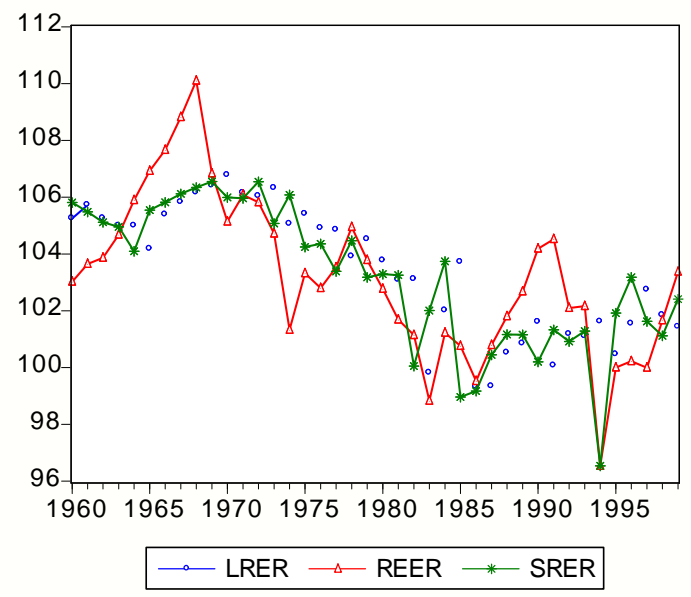

Fig. 5. The REER for Chad, 1960-99 (1995

$$
R E E R=100)
$$
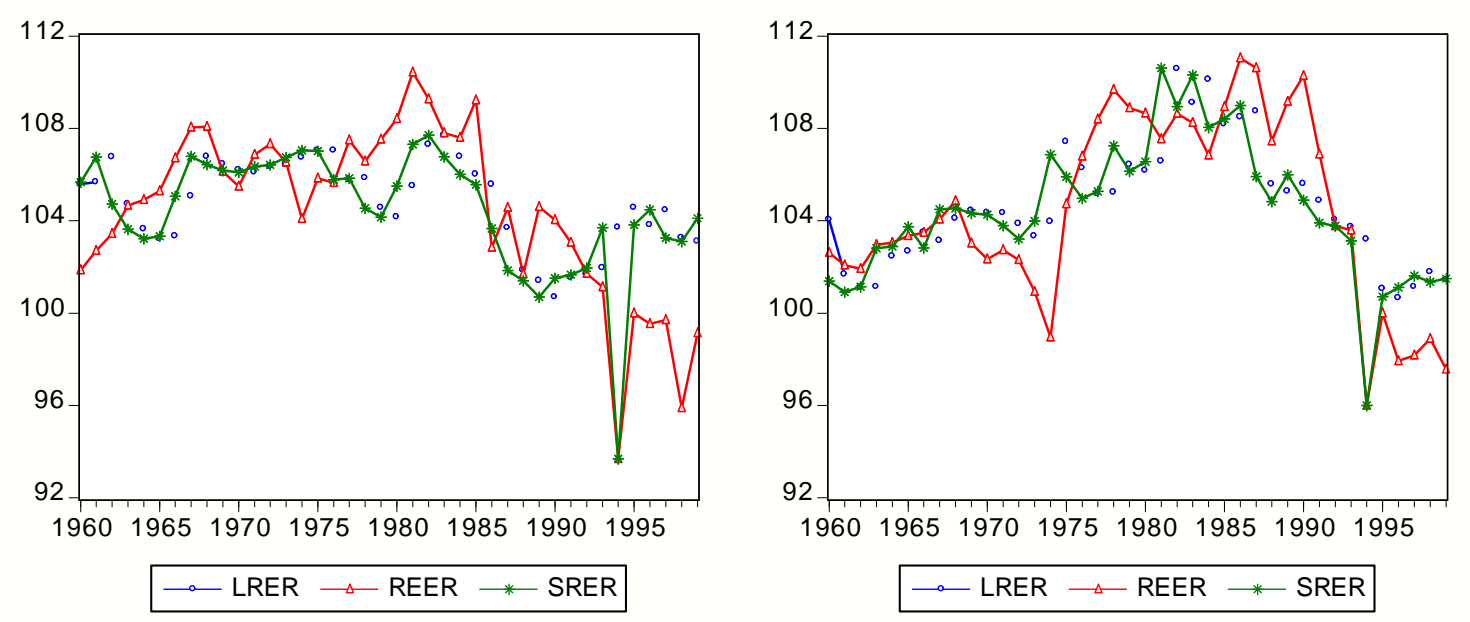

Fig. 7. The REER for the Congo, 1960-99 Fig. 8. The REER for Gabon, 1960-99 (1995

$$
(1995 R E E R=100) \quad R E E R=100)
$$




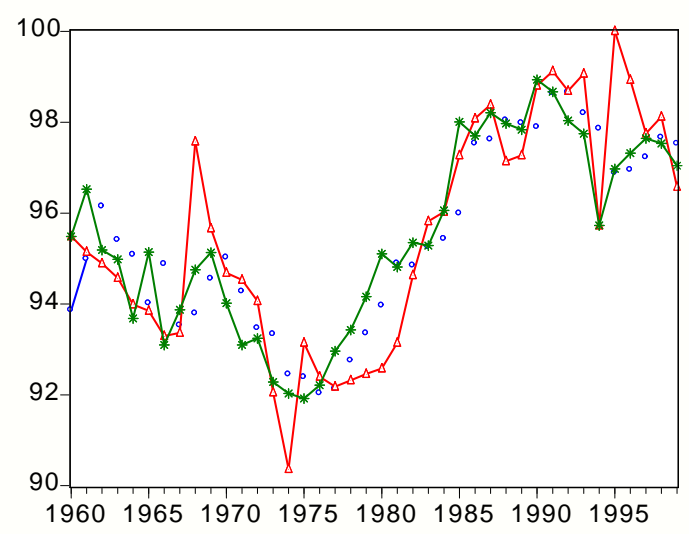

$\multimap$ LRER $\multimap$ REER $\multimap$ * SRER

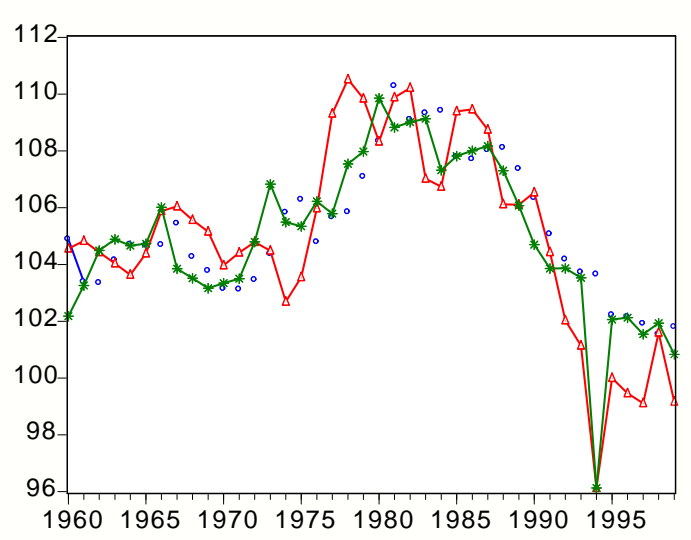

$\multimap$ LRER $\multimap-$ REER $\because$ SRER

Fig. 9. The REER for Mali, 1960-99 (1995 Fig. 10. The REER for Niger, 1960-99 (1995

$$
R E E R=100)
$$

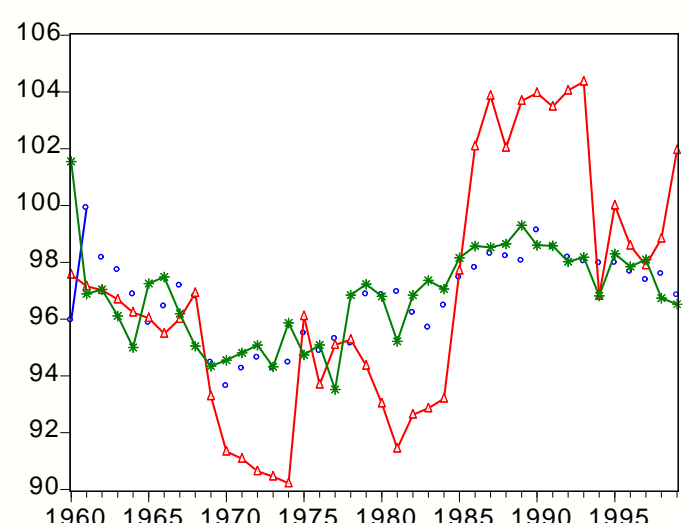

$\multimap$ LRER $\leadsto-$ REER $\rightarrow$ SRER
$R E E R=100)$

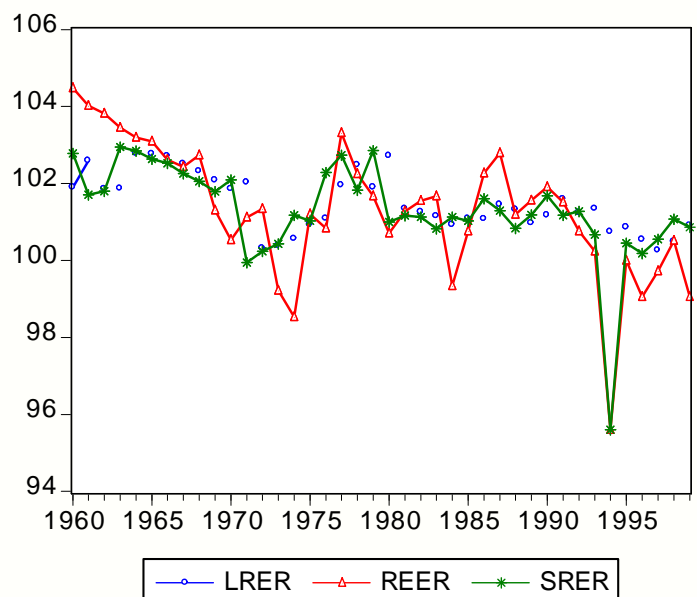

Fig. 12. The REER for Togo, 1960-99 (1995

$R E E R=100)$ 


\section{References}

[1] Bacha, E. and L. Taylor, (1971), "Foreign Exchange Shadow Prices: a Critical Review of Current Theories," Quarterly Journal of Economics, 85, 2: 197-224.

[2] Baffes, J., Elbadawi, I. A., and S. A. O'Connell, (1999), "Single-Equation Estimation of the Equilibrium Real Exchange Rate," in Lawrence E. Hinkle and Peter J. Montiel, (eds.), Exchange Rate Misalignment: Concepts and Measurement for Developing Countries, Oxford University Press.

[3] Banerjee, A., Marcellino, M. and C. Osbat, (2005) "Testing for PPP: Should we use panel methods?", Empirical Economics, No. 30: 77-91.

[4] Breusch, T. and A. Pagan, (1980), "The LM test and its Applications to Model Specification in Econometrics", Review of Economic Studies, 47: 239-254.

[5] Clark, P. B. and R. MacDonald, (1998), "Exchange Rates and Economic Fundamentals A Methodological Comparison of BEERs and FEERs," IMF Working Papers, 7/2001.

[6] Clément, J. A. P., (1994), "Striving for Stability: CFA Franc Realignment", Finance and Development, 31, 2: 10-13.

[7] Coakley, J., Kellard, N. and S. Snaith, (2005), "The PPP debate: Price Matters!", Economics Letters, 88: 209-213.

[8] DeGregorio, J. and H. Wolf, (1994), "Terms of Trade, Productivity, and the Real Exchange Rate", NBER Working Paper, 4807 (July).

[9] Devarajan, S., (1997), "Exchange Rate Misalignment In The CFA", Journal of African Economies, 6, 1: 35-53.

[10] Devarajan, S., Lewis, J. and S. Robinson, (1993), "External Shocks, Purchasing Power Parity and the Equilibrium Real Exchange Rate," World Bank Economic Review, 7, 1.

[11] Devarajan, S. and L. E. Hinkle, (1994), "The CFA Franc Parity Change: An Opportunity to Restore Growth and Reduce Poverty", Africa Spectrum, 29, 2: 131-151.

[12] Direction of Trade Statistics (DOTS) Yearbooks, IMF Publications. 
[13] Dollar, D., (1992), "Outward-Oriented Developing Economies Really Do Grow More Rapidly", Economic Development and Cultural Change, 40, 3: 545-566.

[14] Edwards, S., (1988), "Real and Monetary Determinants of the Real Exchange Rate Behaviour, Theory and Evidence from Developing Countries", Journal of Developing Economies, 29: 311-341.

[15] Edwards, S., (1989), Real Exchange Rates, Devaluation and Adjustment, The MIT Press, Cambridge.

[16] Edwards, S., (1994), "Real and Monetary Determinants of the Real Exchange Rate Behavior: Theory and Evidence from Developing Countries", in John Williamson, (ed.), Estimating Equilibrium Exchange Rates, Institute for International Economics, Washington DC.

[17] Elbadawi, I. A. and R. Soto, (1994), "Capital Flows and Equilibrium Real Exchange Rates in Chile", Policy Research Working Paper, 1306. World Bank, Washington, D.C.

[18] Elbadawi, I. A. and R. Soto, (1997), "Real Exchange Rates and Macroeconomic Adjustment in Sub-Saharan Africa and Other Developing Countries", Journal of African Economies, 6, 3: $75-120$.

[19] Elbadawi, I. A., (1994), "Estimating Long-Run Equilibrium Real Exchange Rates", in Williamson, J., (ed.), Estimating Equilibrium Exchange Rates, Institute for International Economics, Washington, D.C.

[20] Elbadawi, I. A., and N. Majd (1996), "Adjustment and Economic Performance Under a Fixed Exchange Rate: A Comparative Analysis of the CFA Zone", World Development, 24, 5: 939-951.

[21] Faruqee, H., (1995), "Long-Run Determinants of the Real Exchange Rate: A Stock-Flow Perspective", IMF Staff Papers, 42, 1: 80-107.

[22] Feyzioglu, T., (1997), "Estimating the Equilibrium Real Exchange Rate: An Application to Finland", IMF Working Paper, WP/97/109.

[23] Fielding, D., (2002), "The Macroeconomics of Monetary Union: An Analysis of the CFA Franc Zone", Studies in Development Economics. London: Routledge. 
[24] Foroutan, F., (1997), "Preconditions and Sustainability of Reforms", Chapter 5 in J. Nash and F. Foroutan, (eds.), Trade Policy and Exchange Rate Reform in Sub-Saharan Africa (Development Issues, No. 6). Canberra: National Centre for Development Studies.

[25] Ghura, D. and T. J. Grennes, (1993), "The Real Exchange Rate and Macroeconomic Performance in Sub-Saharan Africa," Journal of Development Economics, 42: 155-174.

[26] Giorgioni, G. and K. Holden, (2000), "The Crisis of the CFA Franc zone: the Case of Côte d'Ivoire", Economic Modelling, 19: 531-564.

[27] Hinkle, L. E, and P. J. Montiel, (1999), (eds.), "Exchange Rate Misalignment: Concepts and Measurement for Developing Countries", Oxford University Press.

[28] Im, K. S., Pesaran, M. H. and Y. Shin, (2003), "Testing for Unit Roots in Heterogeneous Panels", Journal of Econometrics, 115: 53-74.

[29] Kaminsky, G., (1988), "The Real Exchange Rate in the Short-run and in the Long-run", Discussion Paper, University of Califonia at San Diego, Department of Economics (August). Processed.

[30] Khan, M. and J. Ostry, (1992), "Response of the Equilibrium Real Exchange Rate to Real Disturbances in Developing Countries", World Development, 20, 9: 1325-1334.

[31] Kim, B. Y. and I. Korhonen, (2002), "Equilibrium Real Exchange Rates in Transtion Countries: Evidence from Dynamic Heterogeneous Panel Models", BOFIT Discussion Papers, 15/2002. Bank of Finland Institute for Economies in Transition.

[32] Krueger, A., Schiff, M. and A. Valdes, (1988), "Agricultural Incentives in Developing Countries: Measuring the Effect of Sectoral and Economywide Policies", World Bank Economic Review, 2, 3: 255-271.

[33] Mark,N. C., Ogaki, M. and D. Sul, (2005), "Dynamic Seemingly Unrelated Cointegrating Regressions", Review of Economic Studies, 72: 797-820.

[34] Montiel, P., (1997), "The Theory of the Long-Run Equilibrium Real Exchange Rate", World Bank, Policy Research Department, Washington, D.C. 
[35] Nurkse, R., (1945), "Conditions of International Monetary Equilibrium", Essays in International Finance, 4 (Spring). Princeton, New Jersey: Princeton University Press, International Finance Section.

[36] O'Connell, PG. J., (1998), "The Overvaluation of Purchasing Power Parity", Journal of International Economics, 44: 1-19.

[37] Officer, L. H., (1982), "Purchasing Power Parity and Exchange Rates: Theory, Evidence and Relevance", Greenwich, Conn.: JAI Press.

[38] Pedroni, P., (1997) "Panel Cointegration: Asymptotic and Finite Sample Properties of Pooled Time Series with an Application to the PPP Hypothesis: New Results" Working Paper, Indiana University.

[39] Pedroni, P., (1999), "Critical Values for Cointegration Tests in Heterogeneous Panels with Multiple Regressors", Oxford Bulletin of Economics and Statistics, Special Issue, November, 61 .

[40] Pesaran, H., Shin, Y. and R. Smith, (1999), "Pooled Mean Group Estimation of Dynamic Heterogeneous Panels", Journal of American Statistical Assosiation, 94: 621-634.

[41] Pesaran, H., Smith, R. and K. Im, (1996), "Dynamic Linear Models for Heterogeneous Panels", in L. Mátyás and P. Sevestre, (eds.), The Econometrics of Panel Data.

[42] Pesaran, M. H. and R. P. Smith, (1995), "Estimating Long-Run Relationships From Dynamic Heterogeneous Panels", Journal of Econometrics, 68: 79-113.

[43] Pesaran, M. H., (2007), "A Simple Panel Unit Root Test in the Presence of Cross-Section Dependence", Journal of Applied Econometrics, 22: 265-312.

[44] Razin, O. and S.M. Collins, (1997), "Real Exchange Rate Misalignments and Growth", Working Paper, 6174, National Bureau of Economic Research, Cambridge, Mass.

[45] Wald, A., (1943), "A Note on the Consistency of the Maximum Likelihood Estimator", Annals of mathematical Statistics, 20: 595-601.

[46] Williamson, J., (1994), (ed.), Estimating Equilibrium Exchange Rates, Institute for International Economics, Washington DC. 